\title{
A Personal Perspective on Biblical History, the Authorship of the Torah, and Belief in its Divine Origin
}

Shawn Zelig Aster

I am a researcher in the fields of biblical and ancient Near Eastern studies, and, in this capacity, have held faculty positions at Yeshiva University and in Israel. I do not view the Bible solely (or even primarily) as a topic for research, but as part of Torah. This personal essay results from issues raised in the course of my teaching, primarily by students in the United States. I encountered a significant number of students who questioned basic religious principles and correlated their doubts about these principles to questions about biblical studies. It seems to me that many of their questions and doubts stem from the perception that there is a direct conflict between faith and science, a perception that is to some extent fueled by the nature of Jewish religious education in the United States. The objective of the following discussion is to argue that no such direct conflict exists in the area of biblical studies.

I do not in any way aim to create complete harmony between science and faith, two worlds based on entirely different principles. Rather, I am to define areas in which the conclusions of academic investigation overlap with principles of faith, and thereby to present, for those interested, an "intellectual space" where reason and faith can coexist. Ultimately, Torah and academic studies ought to have the same objective: truth. Academic studies seek truth by means of knowledge discovered by human intelligence. The Torah, in contrast, recognizes the existence of a level of consciousness above the human intellect, and integrates knowledge gleaned by means of human intelligence with knowledge derived from God's revelation to humankind. 
This idea of revelation is central to classical Jewish belief, by which I mean the belief of Jews throughout the ages, which is grounded in classical Jewish texts. God's revelation to the prophets, and his involvement in the human sphere, have always been seen as a critical aspect of the relationship between humans and God, complemented by humans' voluntary decision to turn to God. As in any human relationship, our decision to turn to God is the product of desire and emotions that are influenced by intellectual experience, though not dependent upon it exclusively. For any relationship to exist, there must be a certain space where emotion and intellect coexist and overlap.

The most fundamental premise of the relationship between Jews and God is that God transcends human experience, meaning that His intellect, abilities, and nature are infinitely superior to those of the most capable humans. On this premise is built the belief that God reveals his will to humans, as well as a more particular expression of this belief: that God chose the People of Israel and gave them the Torah. It must be emphasized that none of these premises can be proven scientifically. Even if evidence were to be found of the gathering of millions of people at the foot of Mount Sinai in the thirteenth century BCE, that would not prove the divine revelation of the Torah. In other words, people accept or reject these premises, which undergird the relationship between Jews and God, without reference to scientific or objective criteria.

Is it possible to base a relationship on unprovable beliefs? The answer is quite simply and clearly affirmative. All relationships are based on subjective beliefs that cannot be proven. I love my wife because she is the prettiest, nicest, gentlest, and kindest of all women. No reasonable person would ask me to prove this. Similarly, the decision to maintain a relationship with the God of Israel is not based upon pure logic, but on unprovable beliefs. These beliefs often stem from personal identity, and they require a certain leap beyond logic, and are therefore called "leaps of faith." I pity the lonely person who does not make at least two such leaps in his life, into faith and love.

\section{Conflict}

If the premises at the heart of the relationship between human beings and God are neither scientifically provable nor disprovable, what then is the source of the conflict between science and faith? The conflict inheres in areas where academic research reaches conclusions which appear to differ from beliefs about the nature of the Torah. Among the most intense areas for this conflict are the authorship of the Torah and the historical authenticity of the biblical narratives. 
The question of the Torah's authorship is, in my opinion, the more difficult and more pivotal of the two. However, I will first discuss the simpler question of historical authenticity, which is central to my own research. This question is fueled by the perception that the knowledge derived from archeology and epigraphy (the study of texts from the biblical world discovered in archeological excavations) contradicts the biblical narrative.

\section{Biblical Narrative and History}

The apparent conflict between the biblical narrative and archeological and epigraphical discoveries is a product of the unrealistic expectation that the events described in the biblical narrative will conform exactly to the events portrayed in archeological and epigraphic sources. The absurdity of this expectation becomes clear when we reflect on the fact that no narrative narrates every single event taking place in a particular time and space. Every narrative selects certain events, emphasizes and presents them, connects them to each other, and describes the main characters in accordance with certain literary decisions. These literary decisions usually reflect the desire for the narrative to present a moral, a message, or a particular portrayal. By means of this process of selection and connection, a narrative that reflects this desire is created. Historical narratives do not differ in this respect from any other narrative.

This point can be illustrated by an analysis of the story of the Exodus from Egypt, which many claim has no historical basis. On the one hand, we do not have a single scrap of historical evidence showing that millions of people migrated from Egypt to the Land of Israel over the course of exactly forty years. Anyone seeking such evidence will be disappointed.

On the other hand, we do have clear knowledge, based on archeological and epigraphic evidence that between the late fourteenth and the twelfth centuries BCE, Egyptian rule weakened in the region of Canaan and Sinai. During this period, many groups of Semitic nomads, some of whom were called "Shasu" in Egyptian writings, began to migrate both within Egypt and through the administrative region that the Egyptians called the "Way of Horus" in the north of the Sinai Peninsula. Egyptian officials found it difficult to control their movements, and at times battled them. ${ }^{1}$

During this period, starting in the late thirteenth century, small settlements, characterized by simple pottery, four-room houses, and multiple sites of terrace farming, were established in the Manasseh Hill Country. ${ }^{2}$ Over the 
course of the twelfth and eleventh centuries, these settlements spread from Manasseh over the highlands of the Land of Israel. Late in the thirteenth century BCE, the Egyptian pharaoh Merneptah wrote of his battles with a Semitic-speaking group called "Israel" who appear to have been located somewhere between Gezer and Galilee. Merneptah's statement alone does not prove that these settlers were Israelites, but there are other arguments strongly suggesting this. Ethnic characteristics found in these early highland settlements also appear in settlements clearly identified with the Israelites from the tenth century onwards (Iron Age II, as it is known to archeologists). ${ }^{3}$ While it cannot be proven conclusively that the Israelites who settled in the land originated among the "Shasu," the evidence for it is very convincing. 4

Do these events correspond to the biblical narrative? In my opinion, the question itself is problematic. Events cannot be compared to a story. Events are the building blocks with which a narrator builds his story. ${ }^{5}$ Therefore, the question ought to be: Are these the historical events that the Torah adapted in its presentation of the narrative of the Exodus from Egypt (Exod. 1-15)? There are many discrepancies between these events and the biblical narrative. A striking example of this is the question of the non-Israelites included among the "Shasu." The Egyptian documents refer to numerous and various groups of "Shasu" (including groups known as Shashu-Se'ir, Shasu-Laban, ShasuEdom, and Shasu-Yahwe). As discussed above, it appears that some of the early Israelites were one group of such nomads. By means of literary techniques, the biblical story focuses on the Israelites and follows their story, yet mentions, en passant, the "mixed multitude [that] went up with them" (Exod. 12:38). The discrepancy between the biblical focus on the Israelites and the Egyptian documents' broader perspective on the Shasu overall is not the result of a historical discrepancy, but rather of the narrative focus of the Bible. It follows, therefore, that the story of the Exodus from Egypt is not an objective description of an historical event, but a narrative interpretation of historical events. As commentary written in a narrative style, the Torah attempts to explain to us the conceptual significance of the complicated events that took place between Egypt and Canaan between the fourteenth and twelfth centuries BCE. The Torah describes the Exodus from Egypt in Exodus 1-15 in a manner that emphasizes that both the Israelites and the Egyptians learned about the sovereignty of God. The climax of this realization is also the climax of the story, at the parting of the Red Sea in Exodus 14-15.

It is perhaps difficult to accept that events that we consider to be of the upmost importance are not emphasized in the contemporary Egyptian 
records. It must be pointed out, however, that emphasis is the prerogative of the narrator. Even when the narrative is constructed from historical events, it is the narrator who decides which events to emphasize. The historian E. H. Carr provided a good example of this in his book What is History?, in his description of a riot over the price of gingerbread sold at a fair in the English town of Stalybridge in $1850 .{ }^{6}$ Can this act of violence be considered an historical fact? According to some historians, this event occupies an important place in nineteenth-century English history because it reflects economic power struggles in industrial cities. According to many others, however, this was a marginal and common incident of no significance whatsoever. It would therefore appear that it is neither strange nor surprising that the biblical narrator focused only on those groups that were to become the "Israelites." Every narrator, including both the English historians described by Carr as well as the narrator of the Torah, chooses to emphasize certain events and ignore others; this is the nature of narrative. $^{8}$

Because of the nature of narrative, we ought not to demand direct correspondence between the biblical narrative and long-term historical processes. Nonetheless, the events at the heart of most biblical stories of a historical nature correspond to a large degree with the events described in archeological and epigraphic sources. An example of this can be found in the book of Joshua. A cursory reading of the book leads to the impression that Joshua led the Israelites to conquer the land within a relatively short period of time. This reading contradicts archeological evidence from the period. However, in addition to contradicting the archeological evidence, this cursory reading stands in complete contrast to the first chapter of the book of Judges, which describes the conquest as slow and gradual and carried out by the tribes, with varying degrees of success.

The aim of the story in Joshua 1-11 is not to describe the process of the conquest in an exact chronological format, but rather to show that the special relationship between God and the People of Israel continued even after the death of Moses. Its purpose is to convey the message: "As I was with Moses, so I will be with you; I will not fail you or forsake you" (Josh. 1:5). Therefore, in chapters 1-5, Joshua reaches levels of achievement equal to or even greater than those of Moses. These successes reveal God's support of him and his deeds: The spies discover the Canaanites' fear of the Israelites, in contrast to the story of the spies in the Torah (Num. 13). The crossing of the Jordan River reveals Joshua's ability to perform miracles by means of the Holy Ark, just as Moses performed miracles with his staff at the parting of 
the Red Sea. The celebration of Passover in chapter 5 signals a turning point in the book: Under Joshua's leadership, the People of Israel had to undergo a transition from the celestial nourishment of manna to a diet based on the natural produce of the land.

At the same time, the people had to undergo a similar transition from leadership through miracles to strictly human leadership. This transition was gradual, and the wars described in Joshua chapters 1-11 are depicted in a way that illustrates this. In the battle of Jericho (Josh. 6), Joshua does not need to fight, only to implement divine strategy and tactics. In the second battle of $\mathrm{Ai}$ (Josh. 8) God determines the strategy (the ambush, 8:2) as well as the timing of this strategy (the tactics in 8:18). All that was left to Joshua was to implement the tactic and determine its exact location (8:3-9). In the following war, against the southern kings, God restricts himself at the beginning to general words of encouragement (10:8), and Joshua determines the battle strategy and implements it (10:9). Afterwards, God functions as a sort of "back-up unit" to Joshua by raining hailstones on the fleeing Canaanites (10:11). God also helps by extending the time available for the battle by making the sun stand still (10:12). This assistance is given in response to Joshua's request, a factor that emphasizes the increasing responsibility taken by Joshua. In the story of the battle in the north, in chapter 11, Joshua continues to receive words of encouragement from God, but develops the strategy and tactics and fights the battle on his own. The stories in Joshua 1-11 are meant to indicate that the People of Israel made a successful transition from miraculous leadership to human leadership. The desire to convey this message determined the choice of events to be included in the story, how they are described, the emphases placed on various aspects, and the order in which they are presented. The stories in Joshua 1-11 are thus not intended to be an objective presentation of the historical events in the period of the settlement.

Some of the events that underlie the narrative descriptions can be corroborated by external historical sources. For example, Hazor was destroyed (according to its excavator) in the thirteenth century BCE, sometime before Egyptian-Canaanite rule in the northern valleys of the Land of Israel collapsed. The battles described in Joshua 10:28-39 were concentrated, among other places, in Makkedah and Eglon. Both of these sites are identified in the area of the Canaanite enclave that continued in the eastern part of the Shephelah, at sites like Tel Yarmut, Tel Eton, and Tel Beit Mirsim, after most of the Canaanite cities in the coastal plain had ceased to exist. ${ }^{9}$ Most of the battles in the book of Joshua, especially in chapters 1-11, took place in areas where there is evidence 
of continued Canaanite presence even after the decline of Canaanite culture in the twelfth and thirteenth centuries.

It is difficult for me to accept Israel Finkelstein's opinion that the conquest narrative might preserve "sherds of memory" but does not reflect the events of the thirteenth century BCE. ${ }^{10}$ On the other hand, there is no doubt that Joshua 1-11 does not describe all the historical events that occurred at the time of the conquest, as is clear from a comparison of these chapters with Judges 1-3. The chapters in Joshua are a narrative that weaves together a nonrepresentative selection of specific incidents from a long, complicated, and convoluted process. This involved the selection of very specific points and their presentation with maximal emphasis on the figure of Joshua. As I mentioned earlier, the aim was to demonstrate the transition from miracles to human agency. Because they are a narrative, these chapters contain a partial selection and presentation of events. Judges 1:17-36 is the only biblical source to describe the complicated and gradual process of the penetration of the Israelites into the Land of Israel from the end of the thirteenth to the beginning of the eleventh centuries BCE, a process increasingly revealed to us by archeological discoveries.

Reading the stories in Joshua with an awareness of the historical and archeological research lends a new perspective to the question of the historical authenticity of the Bible. Not only is there no reason to see tension between archeological/epigraphical research and the study of the Bible, it is often even possible to find a great degree of correlation between the core events of these narratives and historical events. Moreover, this perspective makes it easier to identify the narrative frameworks and to discover the spiritual and moral lessons that the Bible intends to convey.

\section{The Flood Story and the Question of the Authorship of the Torah}

From the relatively simple question of the connection between historical reality and the biblical narrative, I would now like to turn to the more difficult problem: the authorship of the Torah. I will first present the "dry" literary truth: a person who studies the Torah with the aid of literary analytical tools- "according to its exoteric meaning," in the words of Nahmanides-will realize that many of the stories, especially in Genesis, are narrated in "two voices." A classic example of this is the double creation story. Another good example is the story of the Flood. This literary assessment is irrefutable. My question is: What are the theological implications of this assessment? 
If I were to approach the Torah as an objective reader, it would not be difficult for me to conclude that the different voices derive from different authors whose perspectives have been woven together for reasons unknown to me. But because I am not objective, I will take a different approach: the two voices often present different aspects of a certain idea. I will illustrate this approach, which can perhaps be called "deliberate multivocalism," by analyzing the story of the Flood. ${ }^{11}$

The story of the Flood is clearly comprised of two currents, or voices. In one of them (identified in scholarly research as "J") the central problem is expressed in Genesis 6:5: "The Lord saw how great was man's wickedness on earth, and how every plan devised by his mind was nothing but evil all the time." Noah is commanded to take "seven pairs, males and their mates" from every clean animal. Pursuant to this commandment, Noah offers sacrifices at the end of the Flood and upon leaving the ark. In response, God acknowledges that "the devisings of man's mind are evil from his youth," yet nonetheless promises "nor will I ever again destroy every living being, as I have done" (8:21). According to this story, the cause of the Flood was the human inclination to evil, and the solution to this problem is the institution of the sacrificial rite. This institution establishes a clear, universal, social hierarchy: one who offers sacrifices declares his superiority over the sacrificed animals, yet acknowledges God's superiority over him. ${ }^{12}$ From a state of subjugation to God, he must control his evil impulses. Therefore, Noah offers sacrifices and forms an emotional connection with God: "The Lord smelled the pleasing odor" (8:21).

Parallel to this story of emotion and impulse there is another story, told using the name Elohim (a story often identified in research with the "P" source). At its core are legal principles, and the primary problem presented here is robbery and violence (hamas, "lawlessness," in the language of the Bible) (Gen. $6: 11)$. Here there is no mention of the distinction between the number of clean and unclean animals. The problem of violence is solved by the establishment of divine law (9:1-7) and the covenant (9:8-17). The divine decree "whoever sheds the blood of man, by man shall his blood be shed" (9:6) is intended to contain the lawlessness. Just as the institution of the sacrificial rite was a response to the problem of the evil inclination, law is the answer to lawlessness. Just as after the sacrifices God took mercy on humankind and decided to never again to destroy all living things (8:21), so too after the giving of the law, God establishes a covenant in which he promises to protect the human race. A covenant, in the biblical sense, involves the promise of protection granted by the sovereign (God) to the subject (human beings), yet also determines the 
obligations of the subject to the sovereign. These obligations are formulated legally in Genesis 9:1-6. ${ }^{13}$ The Flood itself did not solve either problem, but provided a pretext and an opportunity for the presentation of the solution-in fact two solutions, a solution for each problem.

This analysis raises an obvious difficulty: Why does the Torah tell the same story twice? I think it no less reasonable to explain the duality of the narrative as an intentional and purposeful feature than to argue that the two sources were combined in an arbitrary editing process simply because they were there.

The narrative structure of each of the Flood stories is comprised of five sections: (1) the presentation of the problem; (2) the divine command to Noah to enter the ark with the animals; (3) the Flood itself; (4) after the Flood, an act expressing the connection between God and mankind (the altar in 8:20 and the blessing in 9:1-7); (5) at the end of each story, the divine promise that the Flood would not be repeated $(8: 21-22 ; 9: 8-17)$. This structure is remarkably similar to the Mesopotamian flood story, known to us from the fragments of the Sumerian story of Ziusudra, the Akkadian fragments of the story of Atrahasis, and the adaptation of the story in the eleventh tablet of the Akkadian Epic of Gilgamesh. ${ }^{14}$

In the story of Atrahasis, the problem is that the gods are unable to sleep owing to the noise made by human beings "because they began to increase upon the face of the earth." After repeated efforts to reduce the number of humans in various ways, the gods decide upon a flood. At the end of the flood, Atrahasis offers a sacrifice, and a goddess promises that she will not send another flood. In order to prevent overpopulation, the gods assign various demons to kill babies and also determine that certain women will not bear children. It is important to note that in both the Mesopotamian and biblical stories the flood is not the solution to the problem presented at the beginning of the story. The flood is merely a device that allows a transition from the problem to the solution.

In each of the stories, the selection of the problems and the solutions reflects the human experience and the relationship between God and humankind. Tikva Frymer-Kensky argued that Atrahasis is a type of etiological explanation for the phenomenon of bereavement. It would appear, however, that the story has deeper meaning. The Atrahasis story examines a fundamental social problem in society: the higher echelons need the lower echelons to serve and obey them. In contrast, the Torah posits a different fundamental problem: the main problem of human existence is human self-control. The loss of this self-control is expressed in two ways: (1) lust and unrestrained sexual libido, 
and (2) the desire for power and wealth, and the risk of acquiring these by means of robbery and violence. The "J" story addresses the subjugation of the sexual and animal evil inclination, while the "P" story tells of controlling lawlessness and robbery.

The biblical story of the Flood is a negative response to the Babylonian story in so far as it attacks its basic premise. But the Torah's narrative is not only a polemic. It also teaches a basic truth. Maimonides maintained that many of the laws of the Torah were polemical, directed against idolatry (Guide of the Perplexed, 3:26 and following), and yet have to be observed regardless of their polemical nature. So too, some stories in the Torah have polemical aims, directed against the idolatry pervasive in the ancient world, but still teach basic values, values more apparent to us when contrasted with the ancient Near Eastern stories.

The answer to the question, "Why does the Torah include two contradictory stories?" is related to the need to present the two answers to the question, "What is the basic problem of human existence and what is its solution?". In one story the Torah posits the control of sexual impulses and in the second the control of greed.

The story of the Flood is a true story because it embodies truth. However, it is not a historical story because it is unlikely that the events it relates occurred as described in the real world. Similarly, Maimonides did not classify the stories of the Patriarchs describing angelic revelation as "historical," and thus categorized large sections of the book of Genesis as "ahistorical." In The Guide of the Perplexed he established an important principle regarding the stories in the Torah: we must not assume that the events occurred in the real world when this assumption contradicts reason. (He interprets the appearances of angels in the stories of the Patriarchs as having occurred "in a prophetic vision.")

Thus far I have not demonstrated that the story of the Flood is necessarily of divine origin. I have merely presented an interpretation of the story that enables it to be read as an integral work of divine origin, despite the fact that it includes a double message and does not necessarily correspond to exact historical reality.

\section{When Was the Torah Written?}

The person of faith who reads the Torah and wants to believe in its divine origin faces a very difficult challenge: the question of when the Torah was written. For reasons that I will explain below, it is not easy to date the composition of the 
Torah to the twelfth century BCE, the latest century in which it is possible to place the wandering in the desert and the revelation on Mount Sinai.

The uncertainty regarding the time of the Torah's composition, together with the question of its multiple voices, has led certain scholars to maintain that, while the Torah is of divine origin, it was not dictated by God to Moses in the aforementioned period of time. The following statement by the late Professor Jacob Milgrom clearly reflects this approach: "Instead of understanding the Torah's 'YHWH spoke to Moses' as a claim that the laws that follow came from the mouth of Moses, we can understand the Torah as signaling that the principles underlying the laws are Mosaic principles, emanating from Moses himself." 15

Milgrom accepts the concept of God's revelation to Moses, but limits this revelation to the Ten Commandments, and posits that the rest of the Torah's laws and stories were written later by a scribe who drew from Moses' words. Milgrom compares the process of the composition of the Torah to the Talmudic story of Moses' visit to the beit midrash of Rabbi Akiva, in which Rabbi Akiva expands upon legal principles established by Moses. ${ }^{16}$ According to Milgrom, the later writers of the Torah expanded upon the principles embodied in the Ten Commandments, principles that Moses himself formulated during the revelation.

I do not agree with Milgrom's approach because I see no reason for its constraints. As soon as we accept God's revelation to humankind, a process that can never be proven or even understood by scientific means, what is gained by limiting it to specific content such as the Ten Commandments, rather than the wider scope of "the Torah and the commandments," posited by Maimonides, that includes at the very least the laws of the Torah and their explanations? In my view, the reasons for accepting that the Torah and commandments were given by God in Moses' time, reasons related to faith, outweigh the reasons for dating its composition to a later period. This is not to make light of the reasons for dating its composition to a later period, as I discuss below. These reasons seem to provide the rationale behind Milgrom's proposed limitations on the scope of revelation.

In academic research, it is generally agreed that the Torah was composed in the second half of the First Temple period. Most sections of the Torah do not include a solid chronological anchor that could date the Torah to this time. In addition, we do not have enough linguistic evidence to distinguish between the Hebrew of the beginning of the First Temple period (the tenth century) and the 
Hebrew of the twelfth century. If we accept the dating of the Exodus to the period predating the tenth century, it follows that we must date Moses to that period.

One of the few chronological anchors to a period later than the tenth century are phrases in Deuteronomy 28:49-63 reminiscent of parallels in Akkadian literature-for example, the description of the "ruthless nation" (50) and the word ve-nisahtem (63). Most of the idioms in the Bible influenced by Akkadian and describing political or state phenomena (such as foreign rule or exile) are to be found in books from the period of Assyrian rule, which began late in the eighth century. Their appearance in Deuteronomy 28 is one of the reasons for dating Moses' speech of admonishment (Deut. 28 ) to this period. In my opinion, this problem can be solved in one of two ways. First, it can be assumed that these idioms entered the Hebrew language in an earlier period for reasons unknown to us. This is a faith-based assumption that is very problematic from an academic perspective because it is currently unsubstantiated. ${ }^{17}$ A second possibility is to accept the interpretation of Abraham Ibn Ezra, in the framework of his thesis known as "The Secret of the Twelve," that the Torah contains later additions. In my opinion, this possibility is also preferable to dating all of the Torah, or entire sections of it, to a later period, because it is best not to make important and exalted matters of faith and belief conditional on specific points. It is preferable to identify later additions within the text than to date the entire text to a later period.

On the other hand, there is no scientific way to prove that most sections of the Torah date to the eleventh century BCE or earlier. Nonetheless, in my opinion, it can be easily proven that many of the ideas presented in Deuteronomy, which according to many scholars is one of the latest books of the Torah, were known among the Israelites before the eighth century. It can be proven that large sections of the book of Isaiah were written in the eighth century, and were based on the ideas of absolute monotheism familiar to us from Deuteronomy. In an article on Isaiah 19, I argued, based on literary and historical evidence, that the author of this chapter lived at the end of the eighth century, and was familiar with the language attributed to " $\mathrm{P}$ " in Exodus $1-15 .^{18}$ It is therefore possible to narrow the gap between the latest dating of sections of the Torah that is scientifically credible and the latest dating acceptable from a faith-based perspective to a period of two hundred years, between the eleventh and ninth centuries BCE. It is clear that from a scientific point of view, the more cautious dating, before the eighth century, 
is preferable. However, it is difficult for me to challenge important religious principles on the basis of this preference.

\section{Why Leap?}

I have proven nothing in this article. I have not proven that the Torah is historically authentic, nor that its multiplicity of voices is intentional, nor that its legal contents do not postdate the tenth century. Neither was it my intention to prove these points. On the other hand, I have attempted to show that these points do not contradict science, and that an intellectual space exists that is wide enough to allow someone to believe that God gave the Torah to Moses and yet remain cognizant of what can be proven scientifically. ${ }^{19}$

Another very important question remains unanswered: Why would a person want to believe that God gave the Torah? Why does a person make this "leap of faith"? In my opinion, the answer to this question is personal and emotional, as is any other decision to enter into a relationship. Therefore, I doubt if the reasons that I find for making the leap of faith will help others. I can only say that in times of crisis I turn to the God of my fathers. I am reminded of the words of Jeremiah (2:27) who describes how the People of Israel follow other gods, but in their "hour of calamity" abandon them and turn to the God of Israel, calling out "Arise and save us!" Turning to God in the hour of need reflects the faith, embedded somewhere in the soul of every Jew, that the God of his fathers can save him. The God of our fathers has a specific identity, expressed in His revelation to humankind, His selection of the People of Israel, and His revelation of the Torah.

\section{Endnotes}

1. Evidence of this can be found in the Papyrus Anastasi VI and VII, English translation in William Hallo, ed., Context of Scripture (Leiden: Brill, 2002), 2:20-27 and 3:16-17; and in Raphael Giveon, Les Bedouins Shosou des documents Egyptiens (Leiden: Brill, 1971). A very informative summary can be found in the ninth chapter of Anson F. Rainey and Steven Notley, The Sacred Bridge: Carta's Atlas of the Biblical World (Jerusalem: Carta, 2006). A description of the "Way of Horus," which runs through the biblical land of the Philistines, can be found in Eliezer Oren, "The Establishment of Egyptian Imperial Administration in the 'Way of Horus': An Archeological Perspective from North Sinai," in Timelines: Studies in Honor of Manfred Bietak, ed. Ernst Czerny et al. (Leuven: Peeters, 2006), 2:279-292.

2. For an introduction to this subject see Adam Zertal, "Be-Eretz ha-Prizi ve-ha-Refaim: al ha-Hitnahalut Ha-Yisraelit be-Har Menashe" ['To the land of the Perizzites and the Giants': On the Israelite settlement in the hill country of Manasseh], in Me-Navdut le-Melukha [From 
nomadism to monarchy: Archaeological and historical aspects of early Israel], ed. Nadav Na'aman and Israel Finkelstein (Jerusalem: Yad Ben-Zvi, 1994), 47-69.

3. For a discussion of these phenomena, see Avraham Faust, Israel's Ethnogenesis: Settlement, Interaction, Expansion and Resistance (London: Equinox, 2006).

4. Anson F. Rainey, "Israel in Merneptah's Inscriptions and Reliefs," Israel Exploration Journal 51 (2001): 57-75. It is beyond dispute that a large portion of those who became Israelites were not originally Shasu. But some of those who settled in the thirteenth-twelfth-century highland settlements were certainly nomads, and the Egyptian texts make it clear that the Shasu were Semitic speakers, as were the "Israel" mentioned in Merneptah's inscription. These hints strongly suggest (even without the pictorial evidence) that some of the nomads who formed part of the thirteenth-twelfth-century settlers were those called Shasu by the Egyptians.

5. For a discussion of the stages of development from events to narrative, see Mieke Bal, Narratology: Introduction to the Theory of Narrative (Toronto: University of Toronto Press, 2009), chap. 2.

6. E. H. Carr, What is History? (Harmondsworth: Penguin, 1968).

7. It is also difficult to accept that perhaps the "mixed multitude" constituted the numerical bulk of the People of Israel, while the nucleus who were the descendants of Jacob were the minority. This possibility also does not contradict faith-based beliefs because the Torah demonstrates that familial allegiance does not necessarily indicate genealogical origins. The comparisons of the numbers in the family censuses in the book of Numbers indicates that people moved from family to family and joined families according to their own preferences. On this subject see Naḥmanides' commentary on Num. 26:52-53.

8. For a detailed discussion of the factors that turn events into a story, see Bal, Narratology, $75-77$.

9. Avraham Faust and Hayah Katz, "Philistines, Israelites, and Canaanites in the Southern Trough Valley in Iron Age I," Agypten und Levante/Egypt and the Levant 21 (2011): 231247; David A. Dorsey, "The Location of Biblical Makkedah,” Tel Aviv 7 (1980): 185-193.

10. Israel Finkelstein, "Shechem in the Late Bronze and Iron I," in Timelines: Studies in Honor of Manfred Bietak, 2:351.

11. The story of the Flood in the Torah has been discussed extensively. It is worthwhile to begin with Rabbi Mordecai Breuer's discussion in Pirkei Bereshit [Essays on Genesis], ed. Yosef Ofer (Alon Shvut: Herzog College, 1999), 1:136-206. In the current discussion, I will not analyze the verses closely, but will rather emphasize the connection between the biblical story and the Akkadian version, a connection that, in my opinion, can explain the deliberate multivocalism of the Torah.

12. It is possible to connect the verses that raise the problem of the evil inclination (Gen. 6:5-8) with the verses that present the problem of the "divine beings" and the "daughters of men" (6:1-4), in which the effacing of the hierarchy by means of unusual mating can be seen. The sacrificial rite reestablishes the hierarchy of God, man, and beasts.

13. There is an extensive literature on the meaning of "covenant" in the ancient Near East and its parallels in the Bible. A good introduction to this subject can be found in Dennis J. McCarthy, Treaty and Covenant: A Study in Form in the Ancient Oriental Documents and in the Old Testament (Rome: Pontifical Bible Institute, 1963), 28-48.

14. Tikva Frymer-Kensky has demonstrated that the biblical story is based on the Babylonian story. See "The Atrahasis Epic and Its Significance for our Understanding of Genesis 1-9," Biblical Archeologist 40 (1977): 147-155. See also the more recent article by Jacob Klein, 
"A New Look at the Theological Background of the Mesopotamian and Biblical Flood Stories," in A Common Cultural Heritage: Studies on Mesopotamia and the Bible in Honor of Barry L. Eichler, ed. Grant Frame et al. (Bethesda, MD: CDL Press, 2011), 151-176. For an English translation of the Atrahasis epic, see Benjamin Foster, Before the Muses: An Anthology of Akkadian Literature (Bethesda, MD: CDL Press, 2005), 227-280.

15. Jacob Milgrom, Leviticus, A Book of Ritual and Ethics: A Continental Commentary (Minneapolis: Fortress Press, 2004), 3.

16. Babylonian Talmud, tractate Menahot 29b.

17. Scientific research is based upon the findings that are at our disposal. It is therefore unwise to overturn principles of faith and belief on the basis of current evidence. Who knows what documents will be discovered in the future? Scholarly opinions on matters of dating tend to change over time.

18. "Isaiah 19: The "Burden of Egypt" and Neo-Assyrian Imperial Policy," Journal of the American Oriental Society 135 (2015): 453-470.

19. By "intellectual space" I am referring to a certain range of conceptual possibilities that make it feasible to accept scientifically proven principles as well as basic principles of Jewish faith as formulated by Maimonides. 